\title{
James Q. Wilson: Another View
}

\section{Lawrence M. Mead}

Published online: 31 July 2012

(C) Springer Science+Business Media, LLC 2012
James Q. Wilson died in March. ${ }^{1}$ The ensuing commentary has lauded him as one of the most influential social scientists of his time. He was widely honored, but I do not believe he was influential in any usual sense. In fact, the world mostly ignored what he wrote-yet it rewarded him anyway. How could someone so out of step with his times be so honored? The answers reveal much about the nature of intellectual influence in America today. For all his public eminence, I finally conclude that Jim's leading distinctions were in private life.

Jim was not my teacher. I studied graduate political science at Harvard during his time there, but American politics was not my specialty, so I barely met him. But later, when I began to write about poverty and welfare in America, Jim became a valued mentor to whom I owe much. I read many of his books and articles, and, starting in 1980, we often corresponded.

In all the fields Jim worked in, we find the same paradox: He was honored even though his advice was largely ignored and the trends were against him:

\section{Political Science}

As a political scientist, Jim wrote magnificent books about American government, as good as any. Every scholar in this field knows these titles, as well as Jim's successful textbook, American Government, coauthored by John DiIulio, $\mathrm{Jr}^{2}$ In these and other works, Jim framed these important arguments:

\footnotetext{
${ }^{1}$ An earlier version of this article appeared in Public Discourse: Ethics, Law, and the Common Good, the online journal of the Witherspoon Institute of Princeton, NJ.

${ }^{2}$ Here and below, I draw heavily on Shep Melnick, "Political Science as a Vocation: An Appreciation of the Life and the Work of James Q. Wilson," The Forum 10, no. 1 (2012).
}

L. M. Mead $(\triangle)$

Department of Politics, New York University,

19 West 4th Street, \#209,

New York, NY 10012-1119, USA

e-mail: LMM1@nyu.edu
- A critique of "reform" politics, seen in his early books on local politics: Negro Politics, The Amateur Democrat, and City Politics (written with Edward Banfield). Also seen in Political Organizations and Jim's essays on national politics. Jim recognized that an earnest, dogooding style took over American politics starting in the $1960 \mathrm{~s}$, but he feared that, for all its good intentions, it would exacerbate differences and prevent government getting things done. He preferred an older, less moralistic style where career politicians with practical concerns governed by compromising concrete interests.

- A critique of rational choice, seen especially in Political Organizations and Bureaucracy. Economists such as Anthony Downs or Mancur Olson claimed that they could explain political behavior by reducing it to the self-seeking behavior of individual actors. Jim, more realistically, thought political psychology was more complex. In mobilizing people or organizations, "purposive" (idealistic) and "solidary" (personal loyalty) motivations mattered as much or more than material interests. Purposive motivation was the main engine behind the burgeoning public interest politics that Jim questioned.

- A scheme of types of policy. Wilson reasoned in Political Organizations and in his American Government text that one could understand the different political patterns aroused by different issues in terms how the potential costs and benefits were distributed. Public interest lobbying such as environmental advocacy was an example of "entrepreneurial" politics, where costs are concentrated on the regulated industries but the benefits redound to the entire society. Jim's scheme differed from another influential set of policy types developed by Theodore Lowi and was in some ways more satisfactory.

- A critique of bureaucratic reformism, seen in Bureaucracy and also in Jim's articles and essays. He rejected all simple theories of how to explain or improve bureaucracy, whether coming from Max Weber or modern economists. Bureaucracy could be understood, he believed, only by studying the tasks of the bottom-line 
officials. All depended on how fully that work could be defined and controlled from above. Agencies varied too widely to permit much generalization. Jim commented to me that few theorists of bureaucracy had ever actually studied it first-hand. He and his students did.

All these contributions are widely recognized. And yet during Jim's career, trends in political science methodology were all away from the old-fashioned research methods he used. He drew his information from many sources, including field observation, documents, and the research of others. That eclectic style can lead to robust and important findings, as it did for Jim. Largely, my books are written the same way. But today, most published research in political science is based on rarified mathematical modeling of some kind. Rational choice analysis - which Jim questioned - has become quite influential. Those methods are more precise but far less robust than his and often lead to weak or trivial findings, yet they have come to overshadow academe.

Jim never "modeled" anything. Rather, he sought to explain important mysteries. He insisted that research questions come out of actual politics and government. One should take on big issues, of importance to lay people and not just academics. And to address them, one should emphasize direct contact: first-hand observation and interviews with those involved - what I call laying hands on the institutions. Quantitative data can also serve, but should not dominate research. Yet during Jim's time, political scientists drew their agenda more and more from academic literatures, less and less from the real world. Most of their research was no longer hands-on but conducted from behind their computers, using either rational choice or data analysis of some kind. That often made their conclusions thin and artificial, without the realism Jim's methods achieved. ${ }^{3}$

If much of Jim's work was massively empirical, however, much of it also involved no direct data gathering at all. Instead, he integrated vast bodies of secondary literature and told us what they mean. That synthesizing talent was the chief basis for Political Organizations, Crime and Human Nature (written with Richard Herrnstein), Bureaucracy, and The Moral Sense. In this, Jim was typical of the great Harvard government professors of his time, including my teachers Samuel H. Beer and Samuel P. Huntington. These were great minds who reasoned widely about their subjects based mostly on the research of others. Such methods count for a lot less today. Francis Fukuyama is one of the few prominent political scientists who still uses them. Most academics now use secondary literature poorly. They read superficially and often do not cite earlier research well. They may summarize "the literature" in a field, but only to

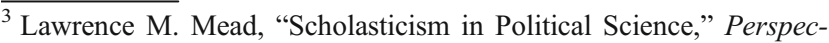
tives on Politics 8, no. 2 (June 2010): 453-64.
}

inventory their specialty. They seldom draw widely and deeply on past scholarship to address major public issues, as Jim did.

Jim and the scholastics differed about the goal of an academic career. Jim took the traditional view that a scholar should pursue significant questions that seemed important to him and, by so doing, construct a personal view of his subject. The life of the mind was an odyssey tending toward wider and deeper knowledge of one's field. Different scholars might construct quite different understandings, and there was no expectation that they would be commensurable. Today's scholastic researchers, however, seek mainly to contribute to a narrow specialty that is defined in advance. They assume that rarified research studies will somehow add up to something significant, but they seldom do. Most of today's political research stirs little interest in anyone except specialists. The capacity to synthesize and interpret research has withered. Mind has lost out to data.

Jim was fortunate to get established at Harvard before the mathematicians took over the universities, provoking battles among academics that endure today. Jim largely ignored those struggles and went his own way. He wrote few academic articles and thus avoided scholastic pressures to follow a strict methodology. He took the methodologists on only to a limited extent. Political Organizations and Bureaucracy were written in part against rational choice. In one lecture he impishly suggested that even the great James Madison would be out of favor in today's political science. But Jim never became a protagonist in the methods wars, and he left no academic school behind. Indeed, to found a school would have violated his skeptical temperament.

So he was a conservative, even a reactionary in academic terms. He was also politically well to the right of most political scientists. And yet he received a long string of honors from the American Political Science Association, including the 1990 James Madison Award for distinguished contributions to political science, the 1994 John Gaus Award for contributions to public administration, the presidency of the APSA in 1991-2, and the 2001 Lifetime Achievement Award. He had no broad influence on his discipline, yet it lauded him. He was famous, but few except his own students follow him. Why? That is the mystery.

\section{An Opening to Policy}

The most radical thing Jim did for political science was to get it more involved in public policy. Traditionally, political scientists have hesitated to take positions on policy issues. To do that, they feared, would be to second-guess the democratic political process, which they had no authority to do. It might also turn them into advocates and so compromise their claims to scientific objectivity. Political science aspired to study only 
the political process, not the policies that came out of it. Economists seldom study politics and government, but they lack the same inhibitions about policy, so most policy experts from academia have been practitioners of the dismal science. Hence the paradox that political scientists study government within telling it what to do, while economists do tell it what to do but ignore it.

Despite this tradition, Jim's early work on urban politics convinced him that one could not understand politics without also grasping the policy issues involved. Prominent among these was crime. Jim embarked on a series of inquiries into crime's causes and cures. His writings on the subject link policy arguments with political and institutional considerations in way very unusual in political science. Jim asked what we might do about crime and then whether politics can tolerate it and whether government can implement it. His conclusions were cautionary, but even to ask such questions vastly expanded the ambition of political science. It no longer meant simply the study of the political process. It also meant using government to improve the human condition. It returned political science to the classical tradition of the master science.

A policy focus also has the great merit of restraining the scholastic tendencies just mentioned. Policy issues tend to be larger and more important than academic specialties. To address them requires reasoning in broader terms and using more kinds of evidence than is now usual in academic research. It is to enter into a public dialogue with voices from outside academe. In his books and many essays about crime, Jim did this superbly.

He did not do so wholeheartedly. In his hands political science did not fully become the policy science it might be. In part that was because he was too cautious on the policy issues, as I note shortly. He also hesitated to say what the public interest means, as one must do to have any view of the merits of policy. American Government, his textbook, combines descriptions of how government works with discussion of policy issues in a mix that is sometimes confusing.

Nonetheless, for a political scientist, Jim gained a rare prominence on the policy arena. Yet as in its methodological trends, the profession did not follow him. In the 1970s, a subfield devoted to public policy developed among scholars of American politics, reflecting the rising prominence of policy problems in national politics, including race, poverty, welfare, and the environment. But in general, these political scientists did not break the mold of the past. They focused mainly on describing the policy process, but not on policy itself. They did not link policy analysis closely to political analysis, using each to illuminate the other, as Jim had suggested. Like other political scientists, they generally asked who won and who lost, but not what government should do. Methodological pressures also forced them this way. It was hard to combine policy and political arguments and still achieve the rigor demanded by journal reviewers. Political scientists have thus largely remained spectators, not protagonists, in the policy wars.

\section{Public Policy}

What did Jim actually say about public policy? These characteristic positions emerge from his writings:

- Skepticism about social policy generally. Jim was a neoconservative, although he disliked that term. He helped found The Public Interest, the influential neoconservative policy journal. He shared the view of most of its authors that Great Society social programs had overreached and failed. Entrenched poverty and race problems could not be solved simply by distributing new benefits and opportunities, as liberal planners imagined.

- Skepticism about "root causes": Especially in Thinking About Crime, Jim rejected the view of most criminologists that crime could be solved only by assuaging its "root causes." We did not know those causes, Jim thought, and, even if we did, to eradicate them was beyond our powers. Rather, government should focus on the things it could do, such as fostering norms for good behavior and deterring crime.

- A defense of incarceration: The crime explosion that began in the 1960s led in later decades to a sharp increase in incarceration, to the point where today more than 2 million Americans are behind bars. Jim regretted that trend, but he saw it as justified as long as government lacked effective alternatives. If society could not reform offenders, it could at least protect society from them. Other criminologists were far more critical.

- Social disorder as the key to crime: With George J. Kelling, Jr., Jim in 1982 published an influential article on "Broken Windows" that treated crime as a reflection of general social disorder. The more society tolerates signs of decay such as broken windows, the more crime seems to be accepted and is bound to increase. Conversely, if order were restored, crime would probably decline.

Society followed this advice only in part. Jim's neoconservative skepticism reflected the social policy trends of the 1970s and 1980s, when government mostly lacked effective antipoverty programs and tolerated growing welfare and prisons as a substitute. The crime field especially promoted pessimism. Whereas at least some antipoverty programs evaluated well, virtually no criminal rehabilitation program showed clear impacts on ex-offenders. 
But Jim's views were overtaken by a new age of optimism in the late 1980s and 1990s. Whereas Great Society programs had been benefit-oriented, a new, more directive form of social program arose that evaluated better. A "new paternalism" sought to link new benefits or opportunities for the poor with requirements for good behavior. Benefits were no longer entitlements, given on economic criteria without reference to lifestyle. Instead, they were conditioned on working or staying in school. Case managers helped recipients get the benefits they needed, but also made sure they worked or studied as they were supposed to do. Work programs linked to benefits were the main basis for the successful reform of welfare in the 1990s, when poor single mothers flooded to work and the rolls dropped by twothirds.

Jim's skepticism about government left him unable to contribute to these advances. I had difficulty persuading him to write the closing chapter of my edited volume, The New Paternalism, which discusses antipoverty programs based on the close supervision of clients. Jim doubted whether such methods could succeed. I once spoke to the board of the Bradley Foundation, on which he sat. I argued for work enforcement as a way to reform welfare, and Jim questioned whether government could do that. Government did do it, albeit not without many problems. He also doubted that public administration could be "reinvented," but without such innovations as contracting and performance management, welfare reform would have achieved what it did.

Jim was uneasy promoting actual programs. Some celebrate "Broken Windows" as a blueprint for improved policing, but it fell well short of that. The article stated correctly that reducing crime depends on restoring social authority, but it said little about how. It suggested that by punishing minor "quality of life" crimes like vagrancy the police could deter larger crimes. But in practice, arresting for petty crime worked not so much as a deterrent as because it proved to be a good way to apprehend more serious offenders. Whereas Jim doubted that police organization could be much changed, reformers like Bill Bratton used performance indicators to sharply improve the management of the police. The police also joined with other agencies in novel "Ceasefire" campaigns that flooded the streets with social workers as well as police to shut down gang violence. The potential of the institutions was greater than Jim perceived.

Jim lived to see his support for incarceration widely questioned. A national movement has arisen to reduce the prison rolls, if only to reduce their immense cost. Paternalistic programming is more likely to endure. The current vogue in criminology is "prison reentry" programs, designed to ease the transition of ex-offenders from incarceration back into society. The best of these programs, as in welfare work, use case managers to help and also oversee clients in their search for work. They have shown clear impacts on their clients, as earlier programs did not. These efforts offer some hope that society can at last gain leverage over crime by means other than just locking people up.

Jim underestimated what government could achieve. The vast majority of political scientists also wanted it to do more than he did. But again, they honored him despite this. In 1977, he won the APSA's Merriam Award for influence on public policy. Note that this was 5 years before he wrote "Broken Windows." And he remained a noted commentator on policy issues to the end of his career, even though he swam against the tide.

\section{Politics}

A third arena for Jim was active politics. Here, too, he was widely heard and honored, but not followed. He was best known among conservative policy experts and intellectuals. They revered him because he expressed so well the cautions they felt about big government. And, very unusually, he did it as an academic. Faculty at the leading universities have become our national aristocracy. They are impressively able and overwhelmingly liberal. They often condescend to the rest of America. Conservatives therefore marveled to hear a voice like Jim's speaking from Harvard, from the very top of the academic world. They were eternally grateful. But at the same time, Jim was uncomfortable, as we have seen, with policy advocacy. He deprecated the rise of aggressive public interest politics, on the right no less than the left.

$\mathrm{He}$ was also uncomfortable with electoral politics. He never aligned himself clearly with either political party. $\mathrm{He}$ never gave a political speech or advocated anything in a political way. Some other conservative academics, such as Bill Bennett or Robert George, were much more forward. And Jim's views of politics were unfashionable. As noted above, he deprecated "reform" movements. Even more, he disapproved of recent trends toward polarization between the parties. Indeed, he reproved our leaders for dividing the public. In 1950, the APSA recommended that American parties become more ideological and distinct, on the British model. But, like many ordinary Americans, Jim preferred the parties as they actually were then-relatively nonideological and overlapping - rather than the more rigid and principled bodies they have since become.

Yet Jim received the Medal of Freedom from President George W. Bush and the Bradley Prize, bestowed by the Lynde and Harry Bradley Foundation. Both these authorities were considerably more partisan than Jim was himself. 


\section{Avenues of Influence}

What was it about Jim that drew honors to him-even though he was largely out of step with his times? One explanation was that he was a superlative public communicator. He knew a great deal about politics, government, and policy (at least domestic), and he was a superb writer. His books were solidly researched yet written in plain language and accessible. His exceptional literacy plus his skeptical temperament also made him a leading essayist. He wrote voluminously for the semi-popular press, such as The Public Interest, Commentary and Atlantic Monthly. He could write intelligently about any subject and make you want to read it. He was also a persuasive speaker. Everything he said was reasonable and insightful.

His aversion to artificial, technical discourse marginalized him in academia, but in the political arena it was a huge asset. It gave him a wider audience than most academics could dream of. One reason he kept his following for so long is that few younger academics could rival him as a public intellectual - their formation had become too narrow. Except for his own students, Jim had few successors within political science. In order to escape scholastic constraints as well as p.c., the nation's intellectual life has been migrating outside the university for some time-to think tanks, the policy class in Washington, and the web. ${ }^{4}$ Academe may soon become a backwater. Jim's own career showed some of that movement.

But at the same time, he kept the university's traditional moral stance: humility about the possibilities of knowledge. He always emphasized hard facts. He stressed how little we know about improving government. He avoided strenuous advocacy. This was not because he shied away from controversy. He never feared to put forward uncomfortable truths, as most of his work showed. He dissented from much that was orthodox in the university, including p.c. But because of his skepticism, he seldom pressed his views hard. He often made no recommendations at all. So he made few enemies. This combination of clarity with caution was rare and admired. This was one reason Jim's passing aroused so little criticism. ${ }^{5}$

On the other stand, this stance may limit his long-term influence. Jim reasoned too close to actual government to advance any general theories, which might carry his name into the future. While his works are clear, they are also complicated. They offer middle-level theories, such as the many motivations behind political action, rather than grand conclusions. Those ideas will likely remain best known to

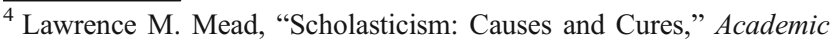
Questions 24, no. 3 (Fall 2011): 300-18.

${ }^{5}$ Glenn Loury, "Much to Answer For," Boston Review, May/June 2012, holds Jim responsible, in part, for the massive run-up in incarceration, especially for blacks, but this was exceptional.
}

other political scientists who read his books. For all his skepticism, Jim criticized big government less forcefully and consistently than some other neoconservatives, such as Nathan Glazer or Irving Kristol. A generation from how, their thinking may be better known than his.

The other route to policy influence is to press one's recommendation more strongly, minimize counterarguments, rebut opponents, and make one's case repeatedly over years. This is what most policy advocates do. As one example, this is what Charles Murray and I did to make our case against traditional welfare. Charles wanted to abolish it, I to condition eligibility on work. ${ }^{6}$ By entering more deeply into policy disputes, and engaging opponents directly, we created more division and resentment than Jim, so we could seldom be recognized in formal ways. But we may have produced more change.

In doing this, we read the academic evidence more strongly to support our views than Jim might have done. But policy argument allows and even requires this. There always is tension between what we already know and what a new policy might bring. Science is precise but backward looking, because data and experience come from the past. Policy analysis is less precise because it is forward-looking, about what some new step will cause. On that spectrum, Jim held firmly toward the academic or scientific end. I made more of a policy argument for work requirements, but with enough attention to academic research so that I could answer critics. Murray ventured even further toward policy argument, making a case against welfare that rested more on principle and a distinct view of human nature than it did on past experience.

Jim's policy arguments were diffident, and that was part of his appeal. The 2000 APSA conference held a panel on policy influence by political scientists. Both Jim and I were mentioned, among others, as having swayed national policy. I was proud of that, but Jim denied that either of us had actually had much effect. He needed to be influential a lot less than I did. People sensed that Murray and I made our arguments, at least in part, out of a personal agenda. Charles wanted to restore the self-reliant society of his Iowa youth, I the dutiful society of my New England forebears. That produced distrust: Were we really interested in solving the social problem in America today? Jim, however, projected only the faintest personal agenda. No scholar ever had so free a mind. His main purposes were simply scholarly-to make sense of whatever he studied. Such purity of intention is rare, and it commanded deep respect.

It is said that a prophet is not without honor except in his own country. For posterity, Jim's problem may be precisely that he was honored in his own country. He never sought

\footnotetext{
${ }^{6}$ However, in writings after Losing Ground Murray has instead argued for replacing all social programs with a guaranteed minimum income.
} 
recognition, but the fact that he received so much of it does suggest that he confirmed the status quo more than he challenged it. The reward for more radical policy critics is not this but rather the many books and articles that are written against us. At least we get the attention of the establishment. We force it to respond. And over timeprovided the evidence still favors us-we see opinions shift in our direction.

\section{Private Life}

Jim's students and associates all say that his personal virtues were even more remarkable than his scholarly achievements. He was humble and reasonable, almost to a fault. Like Socrates, he freely admitted his ignorance. He was always ready to change his views if the evidence changed. He accepted criticism, even from those-like me-who knew far less than he did. I wrote him long comments on his books, and he accepted them. His many honors never turned his head.

Above all, he was a superb mentor. His many students adored him. He gave them close attention and helped make them the fine scholars they became. Although I was not his student, he gave me the same attention. He read the manuscript of my first two books, making wise comments. He helped me find publishers. He coached me in how to address sensitive public issues. My own teachers were not in any way lacking, but Jim's solicitude went far beyond theirs.

In effect, Jim made his students part of his family. His personal life remained deeply private, but the indications are that it was remarkably happy. His wife Roberta was his inseparable companion, and he was close to his children and grandchildren. He also cherished his roots growing up in southern California. In 1987, he left Harvard to join UCLA, even though this was a step down in terms of academic standing, because he could once again live in California. There he built a beautiful house on a hillside in Malibu overlooking the ocean. Toward the end of his life, he moved back to Massachusetts, for the sole purpose of living closer to his grandchildren.

Jim's family and formation seem to have been the reservoir out of which his work came. His life seems to have been remarkably untouched by the struggles over identity, feminism, the family, and multiculturalism that hit the country from the 1960s onwards. For Jim, these were issues to study, but not personal struggles. His social ideal was firmly traditional, modeled on what he knew growing up in the 1950s in Long Beach. Especially, that world had far stronger families than the troubled society he would later write about. In that era, he remarked, unwed pregnancy was still shameful, and the shotgun marriage was still enforced. It now seems as remote as the other side of the moon.

Most policy reformers are uncomfortable in the world as it is. They seek to change it, in part, so they will feel more at home. That certainly is part of my motivation. Jim, however, came out of a traditional experience that he affirmed. He knew and accepted that the world had changed, but mentally he remained in the past. He was already at home, and thus never had to become so. That may be why all his work was in some sense backward looking. Its tone is not angry but wistful. It harks back to a better world, or at least to a less troubled one. Any biographer of James Q. Wilson will have to start with this most blessed and private side of his life.

Finally, the man was more persuasive than his message. Jim's scholarly achievement was great, but his moral legacy is greater. He told the truth as he saw it, and he was exceptionally good to others. That is most of sainthood, in this world or the next. Jim-you will surely get to heaven before me.

Lawrence M. Mead is Professor of Politics and Public Policy at New York University. He is the author of many books on poverty and welfare reform. 